\title{
LEADERSHIP SKILLS' DEVELOPMENT PROGRAMS AT SCHOOL AND COLLEGE LEVEL: AN EVALUATED STUDY
}

\author{
Muhammad Talat ${ }^{1 \star}$, Kamal Haider $^{2}$, Shagufta Shahzadi ${ }^{3}$, Faisal Afzal ${ }^{4}$ \\ ${ }^{1}$ Mr. Research Scholar, Department of Education, University of Karachi, Pakistan, \\ talatwirasat@hotmail.com \\ 2 Dr. Asst. Prof. Chairman of Department of Education (Abdul Haq Campus) \\ Federal Urdu University of Arts, Science and Technology Karachi, Pakistan, \\ kmhrpk@gmail.com \\ ${ }^{3}$ Prof. Dr Faculty of Education, University of Karachi, Pakistan, \\ drshgufta@outlook.com \\ ${ }^{4}$ Dr Head of Research Department at Business Research Consultant, Karachi, Pakistan, \\ brc.khi@gmail.com \\ ${ }^{*}$ corresponding author
}

\begin{abstract}
Education is a process for mental development of an individual; it is a key requirement of a country for better and bright perspective of the nation. The Participation in co-curricular activities in schools and colleges always act as a flashing point for the students, the programs' arrangement at college level for the students boasting their hidden talent for the future leadership role off course the nation's expectation towards the production of young leader, through this nursery an individual prepare for the future challenges. These leadership skills and qualities will affect his whole personality. The best facilitator of mind, body or whole shape of personality like moral and social development moreover the decision making and adjustment qualities along with self-confidence, self-concept, academic aptitude, full of enthusiastic attitude etc. Sports and other out class college's activities play an important role for the development of interpersonal skills for the youngsters' positive leadership future positions. The basic purpose of this study was to examine the role of co-curricular activities in developing leadership skills of school and college students. The scope of the study was limited to the teachers of both school and colleges at Karachi. One hypothesis was formulated for the study. The population of the study comprised of 15 teachers from school and colleges in Karachi.. The data were analyzed through the use of chi square test and percentages through item by item analysis All ten items have been rejected, showed the validity of students' participation in sports and other college's activities.
\end{abstract}

Keyword: Leadership skills, Development, Program, School, College, Level 


\section{INTRODUCTION}

The world advancement through the latest development of information technology rapidly changing the determents of living standard of life naturally effect on working human environment, so the farms and industries rapidly increase in demand of true talented professional as compare to the past when normal ability man power was effecting on major production but nothing in this world for normal or less skills manpower. Computer technology now converted years in months and similarly days into hours than seconds and latest scientific inventions making things more difficult and computable for the people in any working environment and errorless performances of the human always impossible as compare to the machine but do his best through skills and qualities. The advancement of technology demand more talented leader for the industries but leader cannot be produced in flash open eyes. The production of true leader through school and college co-curricular activity is a valid source but mostly talents have been wasted by poor and careless measures and lack of awareness of the institutions especially the school and colleges located in poor locations or located in congested buildings, imagine how much talents wasting due to less sports and other co-curricular activities' programs.

\section{OBJECTIVES}

a) To find out the role of school and college in academic development of the students.

b) To study the opportunities for developing leadership skills available for the students at college and school premises.

c) To find out the intellectual creativity in students while participation in co-curricular activities.

d) To find out the student's academic achievements through sports and other co-curricular activities college's activities.

\subsection{Hypothesis}

There will be no significant relation between co-curricular activities and leadership skills.

\section{CONCEPTUAL FRAMEWORK}

Every nation desires to seek skillful individuals for future leadership role and the prosperity of the country always remains on top for social, economic, political and educational parameters. The leadership skills can be developed through proper understanding the importance of physical activities along the academic development of an individual. The importance a role of institutions is a backbone of this concept through proper arrangement of co-curricular activities which definitely play a major role in developing these leadership skills for the students, process of character building leads to the development of social, academic and physical growth for these youngsters. The researchers often mentioned that sports always play an important role for the growth of hidden skills through these skills an individual should be suited for future successful leadership role of the country. Danish (2002) described that these hidden individuals' skills boast the control power under any stress and tense circumstances in order to minimize the pressure, Dupuis, Bloom, and Loughead (2006), experienced that interpersonal skills and strong character should be developed through school and college's sports activities. During the primary and secondary stages a child needs proper guidance and motivation towards the participation in sports and other activities which polish the hidden talents and skills of an individual (Colucci, 2010, pp.7-8). Classroom teaching demands more flexible patron for transferring knowledge, sometime teacher adopt different strategy like give free hand discussion to the students on given topic which grow habits for thinking and critical analyzing the facts (Lowenthal, \& Wilson, 2010, p.87). The Participation in co-curricular activities at school than college level boast student's strength and capability, these programs arranging by college for the students for the mental and physical development of the students are the source of nourishment for the young potential children to refresh their mind and polished their hidden talent for the future challenges especially incoming tough and hard time where the individual should stand stood through internal abilities and leadership skills other than the routine study schedule and examinations a head. The adjustment quality of an individual is mandatory for professional success and professional development of any individual for discipline and confidence which are the two arms for holding success. The sports give a lesson for accepts facts while losing, a democratic attitude which can be seen during do and die situation of the game which develop harmony among the students essential for any leadership position (Print, 2013, pp.15-19). The student's personality development programs also very useful methods through which an individual learn the mistakes and errors, the repetition usually promote trial and error concept development theory. The intellectual born by nature but polish through at school and college atmosphere like arrangement of athletic competitions are the valid source for individual's emotional, social and moral development at college level especially which act like a factory's 
production of an energetic, healthy and skillful individual for the country (DeMoulin, 2002, pp.297304). Rapidly changes in life styles and working conditions make the students alerts for future challenges. The conflicts both religious and political bases damaging the concepts of welfare state of any nation and the teacher is a key observer who encourage his students in participation games and other competitions to develop harmony and accept the opinion of others, keep calm and cool while game on peak to develop such type of attitude where winning or losing no matter at all(Alan, 2014, pp.13-14).The student's school life mainly help him to understand the facts of real life and an academically strong child can bring his parents' wishes and dream most likely to the fruitful end only when the parents supportive attitude and the basic moral training at home should play an important role for the child who usually play with the others having one thing clear in his mind that winning and losing is a part of game but these thoughts and control much depend on family background of the particular child however this is a practice and learning period for the future leadership role but parents support and encouragement attitude always a head.(Peters, 2013, pp.26-29). The widely accepted phenomenon for development of leadership skills through sports and other co-curricular activities at school level provides the initial phase for mental and physical growth of students at this level (Milner, 2010, p.33). At college level the students try to make them more efficient through polishing their hidden skills for the future leadership position actually this stage is a final phase of their academic and professional growth (Saddleback Educational Publishing, 2013, pp.3-4)..During teaching a teacher use some of the methods through which students understand the difficult terms laws and theories but mostly the teachers use pressurize techniques which is not useful in some cases because these kids are our future, free and pressure less environment and words of appreciation will make them a future leader (Gerver, 2010, p.105). The modern age young people need fundamental changes for example self-identities based on the subject of demand up to the teachers how effectively they ménage through classroom activities although it will pay strongly but teacher own plan under his limitations up to his own skills can work effectively In this modern era everyone need to push himself into the magic world even kids using information technology more effectively. Teachings always demands some changes in parameters therefore the older teacher who can use his experience which is important but without the use of modern technology like computer is mandatory for the teaching now with effective plan too (Fuller, 2010, p.12). The valuable childhood experiences from childhood to younger age should be counted while treatment of such cases through expert counseling and a schools' out class various activities must be counted and the useful significance of future leadership's adjustment for the students will be the huge one. The parents' wishes towards the successful future of their kids right on peaks now but the best solution is to encourage them in participation of school and college's sports and other activities in order to make their children fit and healthy (Houg, 2012, p.130). The school provides solid chances for the students to improve reading and writing skills necessary for sustaining stability of both community and individual, co-curricular activities provide a plate form for students to come together, discuss suitable productive ideas and issues sharing common views and develop stagey to accomplish goals by using educational and motivation skills. Within the community these activities provide good relationship and emotional accepting attitude which lead to foundation of a solid and stable society. Transferring knowledge to the students is not an easy task for the teachers especially at school level as compare to the college level this knowledge can be transferred effectively through the skillful teachers by adopted effective teaching designed for the students' academic growth of the students (Penketh, 2011, pp.5-10).The students' attitude and tolerance are two important factors which can play an important role for their future success, accepting views of others with moral and supporting behavior should be developed sports and other participation in schools and colleges (Wu, 2013, pp.1-2). The participation in these cocurricular programs through suitable arrangement by the institutions is important for the nations' needs of talented leaders (Sylva, 2010, pp.119-20).The global advance environment naturally around the science after day and night hardworking efforts and researches men establish the relationship through satellite, similar type of progress can be developed through scientific knowledge workshop and especial lecture for latest development in science and technology, give some especial task which cover student's lesser time activities (Paul, 2010,p.166). The games always minimize the tolerance level and wider acceptance of individual differences concept for an individual who like to play cricket but do not like football similarly a football player do not has much interest in other games but in case the eleven football players playing under one united team and during do and die situation they play under the instruction of team leader and the coach outside the ground, it is a daily practice for all that the team members give suggestions or instructions to the captain or a sticker and the captain listen carefully and adopt better planning how to defense and attack this is a real sports man sprit and the act of real leadership skills (Frenay, 2010, pp.8-9). The coach also use his skills which he learned through his life experiences through games participation mostly at college level, he understands the capabilities of his players and well observer of infield and outfield attitude equally important for the personal development of the child and sometime his aggressive behavior damage the whole structure of the team while the other team take full advantage of this aggression, at home the child aggression need to be minimized by his parents if not corrected this damage their kid whole future and completely pull him out 
of the leadership role in future. The student's hidden skills and leadership qualities will make the things better for the nation The nation needs more leader who face the hurdle of life quite nicely participation in quiz show for quicker responses and working with others under one project's topic useful for future adjustment and leadership positions. The teacher parents meetings however very important and mandatory for the academic progress and development through which the student's academic and physically activities progress reports has been monitoring, the child achievements both academic and sports activities is a source of projection leadership skills and relation between student and teacher should boast the student's confidence level, monthly progress reports can be transferred through emails or mail service also the informative calls about the negative attitude or aggression of the student must provide the valid recovery time of the student (Gerver, 2010, p.105).The participation in college seminars and workshop is a student's fly zone for successful future flight for development of knowledge and skills, more programs participation give more clear vision of the concepts (Bradly, 2011, p.100). The mental and physical development of the child is a agenda right on top for the educational organizations especially at college level, in whole academic year sports and other competitions' programsl scientific exibutions,book fairs, seminars and study tours are available for students to show their talents through events' platform (McGill, 2013, p.94). The explanations of scientific laws and the topics of history and other subjects can be explained through field trips and visits to a historical places are the most useful events of colleges' and the event of students' participation in seminars is also important for academic and professional growth (Steinberg, 2011, pp.19-20).Technologies making the thing quite unique and different for the development of students' learning, interest properly through seminars, and workshops will make the thing easy for these students for future leadership role (Tremblay, 2010, p.p.217227) The information technology is working in all effective teaching and learning process but always up to the teachers how effectively they involve their students in learning process as all know that the student era rotating the world on his fingertips so naturally the adopted teaching patron and lectures should ran through the computer motivate through the information technology (Moore, 2011, p.p.129-135).

\section{RESEARCH METHODOLOGY}

The study based on survey both qualitative and quantitative approached has been used for collection data. The population of the study consisted of all the teachers of both government and private schools and colleges located at Karachi; teachers from schools and colleges have been selected from each district for data collection. A custom made questionnaire consisting of relevant items was developed; finally analysis of data chi-square was used through SPSS.

\section{FINDINGS}

The finding of survey from question 1, that "Co-curricular activities are the integral part of the curriculum" shows in percentages, Strong Disagree 24.7\%, Disagree 1.3\%, Undecided 1.3\%,Agree42\%,Strong Agree $30.7 \%$, it concluded that the statement of given question is valid.

The finding of survey from question 2 , that "It helpful in developing future leadership in all discipline." shows in percentages, Strong Disagree, $2.7 \%$, Disagree $25.3 \%$,Undecided $6 \%$, Agree $36.7 \%$, Strong Agree29.3 $\%$, it concluded that the statement of given question is valid.

The finding of survey from question 3 , that "It is the best way to build democratic attitude among students" shows in percentages, Strong Disagree 14. \%, disagree $20 \%$, Undecided $7.3 \%$, Agree .28 \%Strong Agree $30.7 \%$, it concluded that the statement of given question is valid.

The finding of survey from question 4 , that "The process of socialization boost through such activities" shows in percentages, Strong Disagree23.8 \% , Disagree 5.2\%Undecided 2.9\%,Agree26.2 \% , Strong Agree29.2 $\%$, it concluded that the statement of given question is valid.

The finding of survey from question 5 , that "Creativity and innovation develop through such activities " shows in percentages, Strong Disagree2.3\%, Disagree 29.1\%, Undecided 1.7\%,Agree32.6 \%, Strong Agree21.5 $\%$, it concluded that the statement of given question is valid.

The finding of survey from question 6 , that "Students learn rules regulations and laws that make them good citizen " shows in percentages Strong Disagree6.4\%, Disagree $23.3 \%$,Undecided6 \%,Agree $5.2 \%$,Strong Agree $51.7 \%$, it concluded that the statement of given question is valid.

The finding of survey from question 7 , that "Students learn to manage time, energy and situations " shows in percentages Strong Disagree6.4 \%, Disagree $14.5 \%$, Undecided $17.4 \%$,Agree $22.2 \%$, Strong Agree36.6 $\%$, it concluded that the statement of given question is valid.

The finding of survey from question 8, that "Success and failure in activities necessary for the training of future life of the students " shows in percentages, Strong Disagree23.3 \%, Disagree $9.3 \%$, Undecided 22.1 
$\%$,Agree $31.4 \%$, Strong Agree $3.6 \%$, it concluded that the statement of given question is valid.

The finding of survey from question 9, that "It provides base for the development of balance personality" shows in percentages Strong Disagree $5.2 \%$, Disagree $5.8 \%$, Undecided 1.2, Agree2.9\%, Strong Agree $72.9 \%$, it concluded that the statement of given questions valid.

The finding of survey from question 10, that "It makes students as global citizen" shows in percentages, Strong Disagree $18.6 \%$, , Disagree $1.2 \%$ Undecided 5.8 \%,,Agree44.8\%,Strong Agree $16.9 \%$, it concluded that the statement of given questions valid.

\section{Co-curricular activities are the valid source of leadership skills' projection, Agree+ Strong Agree total percentage of acceptance $59.31 \%(100 \%)$}

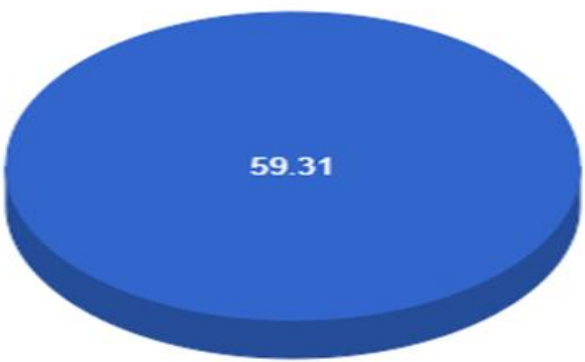

Agree+

Table 5.2: Testing of Chi-square ( $\mathrm{N}=150)$

\begin{tabular}{|l|c|c|c|c|c|c|c|l|}
\hline Items & $\begin{array}{l}\text { Strongly } \\
\text { Disagree }\end{array}$ & Disagree & Undecided & $\begin{array}{l}\text { Strongly } \\
\text { Agree }\end{array}$ & Agree & $\begin{array}{l}\text { Expected } \\
\text { Frequency }\end{array}$ & $\begin{array}{l}\text { Chi-square } \\
\text { Test } \\
\left(x^{2}\right)\end{array}$ & $\begin{array}{l}\text { H0 } \\
\text { Rejected } \\
\text { Accepted }\end{array}$ \\
\hline $1-$ & 37 & 2 & 2 & 63 & 46 & 30 & $98.73^{\mathrm{a}}$ & Rejected \\
\hline $2-$ & 4 & 38 & 9 & 55 & 44 & 30 & $66.73^{\mathrm{a}}$ & Rejected \\
\hline $3-$ & 21 & 30 & 11 & 42 & 46 & 30 & $28.06^{\mathrm{a}}$ & Rejected \\
\hline $4-$ & 41 & 50 & 5 & 45 & 9 & 30 & $60.400^{\mathrm{a}}$ & Rejected \\
\hline $5-$ & 4 & 50 & 3 & 56 & 37 & 30 & $84.33^{\mathrm{a}}$ & Rejected \\
\hline $6-$ & 11 & 40 & 1 & 9 & 89 & 30 & $174.13^{\mathrm{a}}$ & Rejected \\
\hline $7-$ & 11 & 25 & 30 & 21 & 63 & 30 & $51.86^{\mathrm{a}}$ & Rejected \\
\hline $8-$ & 40 & 16 & 38 & 54 & 2 & 30 & $57.33^{\mathrm{a}}$ & Rejected \\
\hline $9-$ & 9 & 10 & 2 & 5 & 124 & 30 & $369.53^{\mathrm{a}}$ & Rejected \\
\hline $10-$ & 32 & 2 & 10 & 77 & 29 & 30 & $113.27^{\mathrm{a}}$ & Rejected \\
\hline
\end{tabular}

\section{Description}

Referring to table of $x^{2}$, the tabulated $x^{2}$ values with $\mathrm{df}=4$ at $\alpha=0.05$ is smaller than the calculated values; hence the $\mathrm{Ho}$ is rejected in all the cases.

\section{ACKNOWLEDGEMENT}

This research was financially supported by the Higher Education Commission (HEC) of Pakistan (Award Letter no. 276.21/ TG/R\&D/HEC/2017, dated: 04-10-2017) 


\section{CONCLUSION}

The student's participation in school and college sports and other co-curricular activities always very productive for them, through this participation students should take better advantages in future life and it best suited for the leadership role as compare to those who do not participate in these activities. The data has been analyzed, it is quite clear that all null hypothesis were rejected and high responses of percentages showed that these outclass activities are the essential part of students' studentship which prepare them for future leadership role. At college level seminars, workshop, cultural events, fashion shows, debate, exhibitions, sports and other activities are the valid exercise for upcoming leadership role. Students admitted initially at schools truly is a stage where these skills can be developed more smoothly and effectively as compare to college level, the participation in co-curricular activities boast the confidence level of these students however most of the talents has been wasted because lack of funds and lack of awareness the effectiveness of these co-curricular activities especially some of the parents who discourage their kids in participation. At college level the process of polishing talent ran more rapidly as it considers the last stage of growth and the development of future leader. A teacher can be used several patron for enhancing student's knowledge and skills additionally use of technology is a pleasant option for new generation for the growth of young potential individual for upcoming leadership role.

\section{REFERENCE LIST}

Alan, D., Reid, E., Paul, H., \& Michael, A. (2014). A Companion to Research in Education. Heidelberg, New York, London: Springer Publishers. pp.13-14

Bradly A.U .Levinson \& Mica P. (2011).A Companion to the Anthropology of Education, ChichesterBlackwell Published, p.100

Colucci, D. S. (2010). Barriers To Learning. Estover Road, Plymouth PL6 7PY, UnitedKingdom: Rowman \& Littlefield Publishers, Inc. pp.7-8

Danish, S. J. (2002). Teaching life skills through sport. In Gatz, M., Messner, M.

A., \& Ball-Rokeach, S. J. (Eds.), Paradoxes of Youth and Sport, 31-47. Albany: State University ofNew York Press.

DeMoulin, D. F. (2002). Examining the impact of extra-curricular activities on the personal development of149 high school seniors. Journal of Instructional Psychology, 29 (4), 297-304.

Dupuis, M., Bloom, G. A., \& Loughead, T. M. (2006). Team captains'perceptions of athlete leadership. Journal of Sport Behavior, 29 (1), 60-78.

Frenay, a. s. (2010). Building Teaching Capacities In Higher Education. Virginia 20166-2102: Stylus Publishing, LLC. pp.8-9

Fuller, C. G. (2010). A Study of Children Starting Secondary School. London: Continum International Publishing Group. p.12

Gerver, R. (2010). Creating Tomorrow's Schools today. New York: ContinuumInternational PublishingGroup. p.105

.Hough, M. (2012). CounsellingSkills and Theory. Bodmin, Cornwall: Bookpoint Ltd, p.130

Lowenthal, P. R., \& Wilson, B. G. (2010). Labels do matter! A critique of AECT's redefinition of the field...TechTrends, 54(1), 38-46.Milton Park, Abingdon, Oxon OX14 4SB.MPG Books, Bodmin, p.87 .

McGill, R. M. (2013). 100 Ideas for Secondary Teachers Outstanding Lessons.London, WC1B 3DP: Bloomsbury Publishing plc,p.94

Milner, H. R. (2010). Culture, Curriculum, and Identity in Education. New York,: Palgrave Macmillan. p.33

Moore, et al. (2011). "e-Learning, online learning, and distance learning environments: Are they the same?". The Internet and Higher Education14 (2) : 129-135

Paul Croll, G. A. (2010). Children's Lives, Children's Futures. London: the MPG Books Group,Bodminand 
King's Lynn. p.166

Peters,A.M. (2013). Citizenship, Education and Violence. Rotterdam: Sense Publisher.pp.26-29

Penketh, C. (2011). Citizenship, Education and Violence. Rotterdam : Sense Publishers,pp.5-10

Print,P. (2013). Civic Education and Competences for for Engaging Citizens in Democracies. Rooterdam : Sense Publishers. pp.15-19.

Saddleback Educational Publishing (2013). Teacher's Educational publishing. U.S.A: Saddleback/ Educational Publishing p.3-4

Steinberg,N. R. (2011). An Inquiry into Science Education, Where the Rubber Meets the Road. Rotterdam : Sense Publisher, pp.19-20

Sylva, F. b. (2010). Child Perspectives and Children's Perspectives in Theory and Practice. New York:Springer Dordrecht Heidelberg London New York. pp.119-120

Tremblay, E. (2010). "Educating the MobileGeneration using personal cell phones as audience response systems in post-secondary science teaching". Journal of Computers in Mathematics and Science / Teaching 29(2): 217-227.

Wu, F. (. (2013). (Re) Imagining The World. NewYork: Springer-Verlag Heidelberg. p.1-2 